\title{
Służba w Women's Royal Naval Service a pozycja kobiet w społeczeństwie brytyjskim podczas II wojny światowej
}

\author{
Tadeusz Wojtych | Wydział Historii, University of Cambridge
}

Słowa kluczowe:

Women's Royal

Naval Service,

społeczeństwo

brytyjskie, kobiety,

historia płci, druga

wojna światowa

Women's Royal

Naval Service, British

society, women,

gender history,

Second World War

\section{Streszczenie}

Wpływ Il wojny światowej na pozycję kobiet jest przedmiotem sporów pomiędzy historykami. Tradycyjna interpretacja problemu, jakoby wojna doprowadziła do równouprawnienia obu płci, jest kontestowana przez historyków takich jak Penny Summerfield czy Arthur Marwick, którzy w wojnie nie widzą motoru większych przemian. W niniejszym artykule przeanalizowano wojenne losy kobiet służących w Women's Royal Naval Service (WRNS, kobiecej organizacji pomocniczej w brytyjskiej marynarce wojennej), wykorzystując przede wszystkim wspomnienia i materiały rekrutacyjne. Omówiono wpływ służby na trzy aspekty życia kobiet: 1) autopercepcję i postrzeganie ich przez społeczeństwo, 2) pozycję względem mężczyzn oraz 3) sytuację finansową. Kobiety w służbie WRNS uczestniczyły w najważniejszych wydarzeniach II wojny światowej, takich jak konferencja jałtańska czy walki o Maltę. Odczuwały dumę z wagi powierzanych im zadań i radość z pełnienia funkcji poprzednio zarezerwowanych dla mężczyzn. Znaczna część z nich traktowała jednak pracę w marynarce wojennej jako tymczasową przygodę, która zakończy się z chwilą zawarcia pokoju. Po wojnie większość kobiet-żołnierzy powróciła do tradycyjnych, przedwojennych ról płciowych.

The impact of Women's Royal Naval Service on the position of women in British society during the Second World War

\section{Abstract}

The impact of the Second World War on the position of women is a subject of debates among historians. The traditional interpretation, which suggests that the war led to the emancipation of women, is contested by historians such as Summerfield and Marwick, who do not see the war as a stimulus for significant change. This article investigates the wartime lives of women who served in the Women's Royal Naval Service (WRNS, women's auxiliary force to the British navy). Main primary sources include memoirs and recruitment posters. The article analyses the influence of service on three aspects of women's lives: 1) their self-perception and image in the eyes of the wider society, 2) their position in relation to men, and 3) their financial situation. WRNS servicewomen participated in some of the most important events of the Second 
World War, such as the Yalta Conference or the fights for Malta. They were proud of the significance of the tasks which they performed, many of which had previously been reserved for men. Most of the WRNS servicewomen, however, treated work in the navy as a temporary adventure, which would end as soon as peace was concluded. After the war most of them returned to their traditional pre-war gender roles.

\section{Wstęp}

Dla Wielkiej Brytanii Il wojna światowa rozpoczęła się we wrześniu 1939 r. i trwała aż do pokonania państw osi w 1945 r. Przez sześć lat Brytyjczycy brali udział w wojnie totalnej, czyli takiej, która angażuje całe społeczeństwo w wysiłek wojenny oraz wymaga masowej mobilizacji ludności (Weigall 2002: 220). Wydarzenia wojenne miały wpływ nie tylko na losy walczących na frontach żołnierzy, ale i na życie zwykłych ludzi przebywających z dala od stref walk. Historycy dyskutują na temat oddziaływania wojny na podziały klasowe, edukację, świat pracy i biznesu, czy pozycję kobiet. Ta ostatnia kwestia jest przedmiotem szczególnych sporów. Tradycyjna interpretacja, jakoby wojna w znacznym stopniu przyczyniła się do równouprawnienia płci, jest kwestionowana przez historyków takich jak Penny Summerfield czy Arthur Marwick, którzy w wojnie nie widzą motoru trwałych przemian (Marwick 1968; Summerfield 1988b: 95-118).

Autor niniejszego artykułu przeanalizował losy kobiet służących w Women's Royal Naval Service (dalej WRNS - kobiecej organizacji pomocniczej w brytyjskiej marynarce wojennej), wykorzystując wspomnienia, plakaty rekrutacyjne i inne źródła. Celem artykułu jest przedstawienie sytuacji kobiet w przedwojennym społeczeństwie brytyjskim, a następnie omówienie wpływu służby w WRNS na trzy aspekty ich życia: ich autopercepcję i obraz w społeczeństwie, pozycję względem mężczyzn oraz sytuację finansową. Kobiety w służbie WRNS uczestniczyły w najważniejszych wydarzeniach II wojny światowej, takich jak konferencja jałtańska czy walki o Maltę. Odczuwały dumę z wagi powierzonych im zadań i radość z pełnienia funkcji poprzednio zarezerwowanych dla mężczyzn. Jednak znaczna część z nich traktowała pracę w marynarce wojennej jako tymczasową przygodę, która zakończy się z chwilą zawarcia pokoju. Choć lubiły swoją służbę, po wojnie w większości powróciły do tradycyjnych przedwojennych ról płciowych. Do przywrócenia przedwojennego ładu, w tym przedwojennej pozycji kobiet, dążył zarówno rząd, jak i zwykli Brytyjczycy.

\section{Sytuacja kobiet w Wielkiej Brytanii w momencie wybuchu wojny}

W przedwojennej Wielkiej Brytanii zarówno opinia społeczna, jak i system prawny narzucały mężczyznom i kobietom określone role i zachowania. Kobiety zajmowały się przede wszystkim domem i dziećmi, a mężczyźni - pracą zarobkową (Summerfield 1988a: 96-97). W latach przedwojennych w świadomości Brytyjczyków silnie utrwalił się wizerunek kobiety jako żony i matki, która dba o życie rodzinne. Kiedy mężczyźni zostali objęci poborem w pierwszych miesiącach wojny, przedstawiciele 
rządu byli przekonani, że wizja czekającej w domu kobiety podtrzymuje morale żołnierzy mężczyzn (Bruley 1999: 93). Podobnymi kategoriami myślało również wiele kobiet. Dobrym przykładem jest Nella Last, która w trakcie wojny prowadziła pamiętnik dla projektu Mass Observation. Last nie chciała porzucić domu rodzinnego z obawy przed wyrządzeniem przykrości swojemu walczącemu na froncie synowi (Last 2006: 122). Wielu kobietom pozostawała więc służba na "froncie kuchennym", który - choć według publikacji z czasów wojny był „kluczowy dla zwycięstwa” - podporządkowywał kobiety mężczyznom: ich główną funkcją było przygotowywanie jedzenia dla swoich mężów i dzieci' (Gardiner 2005: 181). Pozycja mężczyzn jako głównych żywicieli rodzin była usankcjonowana prawnie. W przypadkach, kiedy to państwo ustalało pensje, kobiety zarabiały mniej niż mężczyźni zatrudnieni na tych samych stanowiskach. Taka sytuacja miała miejsce wśród pracowników oświaty czy w administracji (Rowbotham 1999: 244-245; Bruley 1999: 95). Pomimo prawodawstwa, które częściowo znosiło dyskryminację pracowników państwowych ze względu na płeć czy stan cywilny (jak na przykład Sex Disqualification (Removal) Act z 1919 r.), kobiety zamężne były wykluczone z wykonywania niektórych zawodów, takich jak lekarka czy nauczycielka (The National Archives [1919]; Rowbotham 1999: 244). Warto zaznaczyć, że ograniczenia te dotyczyły przede wszystkim zamężnych kobiet z klasy średniej. Kobiety samotne mogły pracować, niekiedy na bardzo odpowiedzialnych stanowiskach, a nawet pobierać wysokie pensje. Oczekiwano od nich jednak, że w momencie założenia rodziny porzucą swoje dotychczasowe kariery na rzecz wychowywania dzieci i opieki nad domem.

Warto jednak zaznaczyć, że w pierwszej połowie XX w. podejście do roli kobiet w społeczeństwie zaczęło się zmieniać. Coraz więcej z nich podejmowało pracę zarobkową (Calder 1969: 331). Podczas gdy na początku zeszłego stulecia pracowało jedynie $25 \%$ wszystkich kobiet w wieku produkcyjnym, to odsetek ten stale wzrastał, osiągając poziom 34\% w 1934 r. (Domenico, Jones 2006: 2; Summerfield 1988a: 98). Zwiększonej obecności wykształconych kobiet na rynku pracy sprzyjało prawodawstwo, które otwierało dla nich niektóre zawody wymagające wysokich kwalifikacji; na przykład wspomniany Sex Disqualification (Removal) Act umożliwiał kobietom zostanie radcami prawnymi (The National Archives [1919]). Uchwałami parlamentu brytyjskiego z lat 1918 i 1928 kobiety zostały objęte czynnym prawem wyborczym. Ponadto od 1918 r. mogły kandydować do Izby Gmin (House of Commons Information Office 2010: 3). Co ciekawe, pierwszą parlamentarzystką, wybraną w 1918 r., była polska hrabina irlandzko-angielskiego pochodzenia, Constance Markievicz (House of Commons 2010: 4). W momencie wybuchu II wojny światowej w Izbie Gmin zasiadało 12 kobiet (Rowbotham 1999: 224). Choć więc w 1939 r. świat pracy i polityki wciąż zdominowany był przez mężczyzn, w społeczeństwie brytyjskim zaszły widoczne zmiany - kobiety na trwałe weszły do życia publicznego.

\footnotetext{
1 Tłumaczenie autora.
} 


\section{Co zmienił wybuch wojny?}

Gdy Wielka Brytania zaangażowała się w II wojnę światową we wrześniu 1939 r., funkcjonowanie zarówno aparatu państwowego, jak i większej części społeczeństwa zostało podporządkowane wysiłkowi wojennemu. Nie sposób wymienić wszystkich zmian, które przyniósł wybuch wojny. Celem tej części artykułu jest przeanalizowanie tych zmian, które były najbardziej brzemienne w skutki dla kobiet.

Już we wrześniu 1939 r. rozpoczęto pobór mężczyzn do armii (Summerfield 1988b: 102). Dla wielu kobiet oznaczało to odizolowanie od ojców, mężów, braci i synów, a często również od jedynego źródła utrzymania. Choć poborowi otrzymywali żołd, był on znacznie niższy niż pensje cywilne i często nie wystarczał na utrzymanie całej rodziny (BBC News 2006). Ponadto w obawie przed niemieckimi nalotami dzieci z większych miast (około 1,5 mln w 1939 r.) na czas wojny ewakuowano w bezpieczniejsze miejsca (Calder 1969: 37; Hellbeck 2015: 331). Co więcej, w rezultacie przekierowania gospodarki na tory wojenne zwolniono około 175 tysięcy z zatrudnionych przed wojną kobiet (Gardiner 2005: 515). W rezultacie tych zmian kobiety niejednokrotnie zostawały same i bez środków do utrzymania. Taka sytuacja pozbawiała je niektórych obowiązków, a zarazem dodawała nowych - aby się utrzymać, były zmuszone podjąć pracę zarobkową.

W miarę trwania działań wojennych zarówno armia, jak i przemysł brytyjski zaczęły odczuwać brak ludzi. W 1941 r. rząd podjął decyzję o poborze kobiet (Summerfield 1988b: 102). Tym samym Wielka Brytania stała się pierwszym państwem na świecie, które ogłosiło ich przymusowy pobór (Calder 1969: 267; Gardiner 2004: 504). Mobilizacja była częściowa, a kobiety mogły wybrać pracę - na przykład w przemyśle zbrojeniowym - lub służbę w organizacjach pomocniczych armii brytyjskiej (Calder 1969: 268). Te ostatnie zostały utworzone przy większości rodzajów sił zbrojnych. Kobiety służące w Women's Auxiliary Air Force (WAAF) wspomagały lotnictwo, w Auxiliary Territorial Service (ATS) - siły lądowe, a w Women's Royal Naval Service (WRNS) - marynarkę wojenną (Bruley 1999: 102-103; Calder 1969: 54). Wskutek mobilizacji wiele kobiet porzuciło swoje tradycyjne role w społeczeństwie na rzecz zadań poprzednio zarezerwowanych dla mężczyzn. Kobiety niezamężne bywały zmuszone do tymczasowej zmiany miejsca zamieszkania (Bruley 1999: 94-95) - działo się tak na przykład w wyniku zatrudnienia w fabryce oddalonej od domu bądź na skutek skoszarowania.

\section{Czym było WRNS?}

Women's Royal Naval Service (WRNS) to służby pomocnicze brytyjskiej marynarki wojennej, które istniały już w trakcie I wojny światowej, ale w 1919 r. zostały rozwiązane. Wraz ze wzrostem niepokojów w Europie w latach 30. brytyjski rząd i administracja zaczęły ponowne rozważać powołanie kobiet w szeregi wojska (Mason 2011: 34). WRNS utworzono na nowo w 1939 r. Początkowo przyjmowano wyłącznie ochotniczki, 
a później również kobiety objęte poborem. Choć w 1935 r. dowództwo marynarki wojennej szacowało zapotrzebowanie na około 3 tysiące kobiet w służbach pomocniczych, liczba członkiń systematycznie wzrastała: w grudniu 1941 r. było ich 24 095, rok później - już 40 415, a w grudniu 1944 r. - aż 73955 (Mason 2011: 35; Fletcher 1989: 41, 55, 80). Dla porównania - we wszystkich żeńskich formacjach pomocniczych służyło około 500 tysięcy kobiet (Marwick 1968: 291-292). WRNS była więc formacją doborową: księżniczka Anna określiła kobiety, które w niej służyły, jako „unikatowy gatunek"2 (Mason, 2011: VII). Organizacja cieszyła się też popularnością wśród samych kobiet: gdy na początku 1939 r. dowództwo marynarki wojennej testowało proces rekrutacyjny na wypadek wojny, na półtora tysiąca miejsc w WRNS zgłosiło się 20 tysięcy kandydatek (Mason 2011: 35).

Współczesna historiografia dotycząca WRNS nie jest obszerna. Historycy, którzy badają sytuację kobiet okresu II wojny światowej, podchodzą do problemu bardziej ogólnie, starając się przeanalizować wpływ całości doświadczeń wojennych na role płciowe. Nieliczni badacze, którzy koncentrują się na WRNS, jak na przykład Chris Bailey (1993: 55-64), najczęściej zajmują się analizą wspomnień konkretnych kobiet żołnierzy. Wyjątkami są książki Ursuli Stuart Mason (2011) Britannia's Daughters: The Story of the WRNS oraz Marjorie H. Fletcher The WRNS: A History of the Women's Royal Naval Service. Są to publikacje popularnonaukowe napisane nie przez historyków akademickich, a przez byłe członkinie WRNS. Tym bardziej godna podziwu jest duża ilość danych statystycznych przeanalizowana przez obie autorki i dbałość o szczegóły.

Autor niniejszej pracy przeanalizował wspomnienia zgromadzone przez British Broadcasting Corporation w ramach projektu WWII: People's War ('Il wojna światowa: wojna narodu'), jak również dane statystyczne, materiały filmowe, plakaty rekrutacyjne i inne źródła. Dzięki takiej różnorodności źródeł możliwe stało się bardziej kompletne omówienie wpływu służby w WRNS na pozycję kobiet. Wpływ wojny na życie kobiet w Wielkiej Brytanii jest tematem niezwykle obszernym. Niniejszy artykuł nie aspiruje do przeprowadzenia wyczerpującej analizy; celem autora jest raczej wskazanie luk w historiografii i naszkicowanie możliwych dalszych kierunków badań, a jednocześnie przybliżenie czytelnikom w Polsce tematu, który dotychczas nie doczekał się wielu opracowań w języku polskim.

\section{Jak kobiety służące w WRNS postrzegały siebie i jak były postrzegane?}

Arthur Marwick (1968: 291-292) twierdzi, że większość z pół miliona kobiet służących podczas wojny w brytyjskich siłach zbrojnych była ochotniczkami. Kobiety często podejmowały jednak wybraną przez siebie pracę, aby uniknąć mobilizacji i skierowania w przypadkowe miejsce (Smith 1986: 213-214). Wspomnienia kobiet służących w WRNS sugerują, że podobnie mogła wyglądać sytuacja w siłach zbrojnych - kobiety zgłaszały się tam dobrowolnie, gdyż mogły wtedy wybrać formację, w której będą

\footnotetext{
2 Tłumaczenie autora.
} 
służyć. Jak wspomniano powyżej, WRNS cieszyło się popularnością: o stosunkowo niewielką liczbę miejsc nierzadko konkurowało wielokrotnie więcej kandydatek. Olive Swift (2004), która została żołnierzem tej formacji w 1941 r., z dumą wspomina pomyślne ukończenie procesu rekrutacji. Jak twierdzi, została przyjęta dzięki swojemu zdrowiu i dobremu wykształceniu (Swift 2004). Kobiety odczuwały dumę z tej służby, w szczególności, gdy powierzane im zadania wymagały specjalistycznych umiejętności i były istotne dla działań wojennych. Przykładem jest Joan Schwarz, która ukończyła kurs dla szyfrantek i towarzyszyła Winstonowi Churchillowi podczas konferencji jałtańskiej - jednego z najważniejszych wydarzeń dyplomatycznych II wojny światowej (Swift 2004). Marion (nazwisko nieznane) służyła w Sekcji Y do zadań specjalnych. Nasłuchiwała ona niemieckich wiadomości o brytyjskich rozbitkach na Morzu Północnym i Kanale La Manche. Dzięki temu brytyjskie patrole mogły ich ratować i zapobiegać trafieniu do niewoli. Marion (2003) wspomina tę pracę jako niezwykle interesującą. Była dumna z tego, że bezpośrednio przyczyniła się do ratowania życia ludzkiego. Inne kobiety z WRNS po przeszkoleniu zajmowały się naprawą statków w portach (jako spawaczki i cieśle), przygotowywaniem prognoz meteorologicznych, czy - co było zajęciem szczególnie niebezpiecznym - patrolowaniem wód przybrzeżnych i wypatrywaniem min morskich (Gardiner 2005). Choć nie brały bezpośredniego udziału w walkach ani nawet nie mogły nosić broni, wykonywały zadania uprzednio zarezerwowane wyłącznie dla mężczyzn. Skutecznie wypełniając rozkazy w WRNS, przyczyniały się do łamania stereotypów dotyczących rzekomo niższych umiejętności kobiet i ich podrzędnej roli w armii.

Owe rewolucyjne zmiany były zauważane przez prasę brytyjską i zagraniczną. Artykuł o kobietach żołnierzach WRNS pojawiał się nawet w czasopiśmie naukowym: w 1942 r. Anne Higham w amerykańskim czasopiśmie „Journal of Educational Sociology" opublikowała artykuł pod tytułem Women in Defense of Britain: An Informal Report ('Kobiety w obronie Wielkiej Brytanii: raport nieformalny'). Autorka - Amerykanka mieszkająca na stałe w Anglii - docenia odwagę kobiet służących w organizacjach pomocniczych. Podkreśla, że wykonują one tę samą pracę, co mężczyźni („nie istnieje już praca wyłącznie dla mężczyzn")3 (Higham 1942: 293-300). Takie publikacje uświadamiały czytelnikom w Wielkiej Brytanii i za granicą wartość kobiet jako pracowników i żołnierzy, przyczyniając się do obalania tradycyjnego mitu o tym, jakoby kobiety nie mogły pracować tak samo dobrze jak mężczyźni (naturalnie dziś nie sposób nie zauważyć, że kryterium dla uznania wartości kobiet wciąż było ich podobieństwo do mężczyzn). Kolejnym źródłem informacji o WRNS dla społeczeństwa były materiały rekrutacyjne. Na plakatach, które zachęcały do wstępowania w szeregi tej organizacji, kobiety żołnierze przedstawiane były w mundurach, $z$ okrętami marynarki wojennej $w$ tle (The Open University, bd). Wynikało z nich, że kobiety przyczyniają się do obrony ojczyzny. Podobny przekaz zawiera krótki film z 1942 r., zachęcający kobiety do dołączenia do sił pomocniczych: obrazy kobiet w mundurach WRNS, ATS i WAAF pokazywane są razem z ujęciami okrętów wojennych, czołgów, eskadr samolotów i szturmujących żołnierzy.

3 Tłumaczenie autora. 
Obrazy te opatrzone są komentarzem narratora skierowanym do potencjalnych rekrutek: ,jesteś niezbędna dla [brytyjskiej] ofensywy"4 (Recruiting Women 1942). Na innym filmie z 1943 r. brytyjscy widzowie mieli okazję zobaczyć królową Elżbietę l odbierającą defiladę członkiń WRNS (Women of the Navy 1943). Przemarsz przed samą monarchinią - przypominający defilady żołnierzy mężczyzn - gloryfikował WRNS i ich wkład w brytyjski wysiłek wojenny. Takie materiały mogły mieć istotne znaczenie dla kształtowania opinii publicznej, gdyż ich przekaz docierał do wielu osób obojga płci.

Dla kobiet spędzających swoje dni na pracy wokół domu i rodziny służba w WRNS była nieoczekiwaną odmianą. Kobiety żołnierze nie tylko wykonywały zadania inne niż te, którymi zajmowały się do tej pory, ale również zmieniały swój wygląd, na przykład poprzez noszenie spodni czy obcinanie włosów na krótko. W służbach pomocniczych taką fryzurę nazywano freedom cut ('fryzura wolności') (Summerfield 1998a: 91). Niewątpliwie te zmiany w modzie były częściowo podyktowane przez względy praktyczne, jednak istotne jest również ich znaczenie symboliczne - kobiety podkreślały w ten sposób swoją równość z mężczyznami służącymi w armii. Według Angusa Caldera (1969: 400) kobiety, które służyły w służbach pomocniczych - w znacznie większym stopniu niż te pracujące w przemyśle - odrzuciły przekonanie o nierówności kobiet i mężczyzn i po wojnie liczyły na możliwość niezależnego decydowania o własnym życiu. Choć więc służba często wiązała się z trudną pracą, zmęczeniem i tragediami wojennymi, to kobiety zyskiwały poczucie sprawczości i dostrzegały potencjał w swojej mobilności zawodowej. Po wojnie niektóre z nich przekwalifikowały się, aby wykonywać pracę bardziej im odpowiadającą. Przykładem jest Gwen Morgan (2005), która przed wojną była pracownikiem biurowym w firmie ubezpieczeniowej, a po demobilizacji z WRNS stwierdziła, że zmieni pracę na bardziej dla niej interesującą i została aptekarką. Wpływ na tę decyzję miała służba w armii. Jak wspomina: ,całość doświadczeń ze służby w WRNS sprawiła, że wyszłam ze swojej skorupy"5 (Morgan 2005).

\section{Pozycja wobec mężczyzn}

Chociaż zaczęto inaczej postrzegać kobiety, to jednak nadal podkreślano ich niższą pozycję w stosunku do mężczyzn. Kobiety żołnierze WRNS były uznawane za mniej wartościowe i mniej kompetentne niż mężczyźni służący w Royal Navy. Nie mogły one nosić broni ani brać bezpośredniego udziału w walce, a większość z nich pełniła jedynie role pomocnicze (Summerfield 1998a: 88-89). Liczne plakaty rekrutacyjne WRNS opatrzone były hasłem „Wstąp do WRNS i uwolnij mężczyznę dla floty" ${ }^{6}$ (The Open University, bd).W trakcie pokoju to mężczyźni zajmowali się obsługą okrętów i zadaniami pomocniczymi, a kobiety w ogóle nie mogły być żołnierzami. W momencie wybuchu wojny mężczyźni zajęli się czynną obroną ojczyzny, a kobiety zostały dopuszczone do czynności pomocniczych. Taki obraz wyłania się z filmu W.R.N.S. At The Helm (1944):

\footnotetext{
4 Tłumaczenie autora.

5 Tłumaczenie autora.

6 Tłumaczenie autora.
} 
choć kobiety żołnierze wykonują zajęcia przypisane uprzednio mężczyznom, takie jak sterowanie niewielkim statkiem czy cumowanie w porcie, to jednak swoją pracą jedynie służą mężczyznom z Royal Navy, którzy zajmują się właściwą walką. Choć więc dzięki służbie w WRNS kobiety mogły podejmować zajęcia uprzednio zarezerwowane dla mężczyzn, to wykonywane przez nie czynności wciąż były postrzegane jako mniej ważne. Takie wnioski z analizy sytuacji w siłach zbrojnych uzupełniają tezę Penny Summerfield, która prześledziła losy kobiet zatrudnionych w przemyśle i stwierdziła, że "dynamika podporządkowania jednej płci wobec drugiej nie uległa transformacji pomimo zmian [we wzorcach zatrudnienia] - kobiety wciąż podejmowały się zadań podrzędnych wobec tych, którymi zajmowali się mężczyźni"7 (Summerfield 1998a: 80).

W niektórych przypadkach dochodziło jednak do częściowego odwrócenia tradycyjnych ról płciowych. Mason (2011:47) opisuje przypadek służącej w WRNS Audrey Coningham: w czerwcu 1942 r. okręt, którym podróżowała, został storpedowany i zatonął. Coningham oddała swoją kamizelkę ratunkową marynarzowi Royal Navy, który miał problem z utrzymaniem się na powierzchni wody. Za ten czyn Coningham została później wyróżniona przez dowództwo. Sytuacja taka nie była jednak normalna ani nawet pożądana - wręcz przeciwnie, zaszła ona w nadzwyczajnych warunkach bitewnych. W filmie o WRNS na Bliskim Wschodzie to mężczyzna, prawdopodobnie z Royal Navy, wydaje jedzenie kobietom żołnierzom w kuchni polowej. Jednak, podobnie jak w poprzednim przypadku, nie jest to sytuacja standardowa: obozowisko wojskowe, w którym nakręcono film, jest prowizoryczne, a kobiety znajdują się daleko od Wielkiej Brytanii (Wrens in The Middle East 1942). Podczas codziennej służby w kraju kobiety żołnierze zazwyczaj nie były oficjalnie traktowane na równi z mężczyznami. Na przykład w Liverpoolu "wrenki" uczestniczyły w organizacji szkolenia taktycznego ze zwalczania łodzi podwodnych dla oficerów Royal Navy. W trakcie symulowanych bitew to kobiety żołnierze kierowały łodziami przeciwnika, jednak pozostawały one schowane za ścianą tak, aby oficerowie - mężczyźni - do końca nie dowiedzieli się, przeciw komu walczyli (Mason 2011: 50). Pokazuje to, że choć w praktyce kobiety mogły być równymi partnerami dla mężczyzn, to oficjalnie marynarka wojenna nie przyznawała tego nawet przed swoimi własnymi oficerami.

Warto również zwrócić uwagę na to, że pomimo warunków wojennych kobiety żołnierze WRNS czuły presję, aby - tak jak przed rokiem 1939 - dbać o wygląd zewnętrzny. Podkreślają to zarówno materiały rekrutacyjne, jak i indywidualne wspomnienia. $\mathrm{Na}$ filmie rekrutacyjnym i plakatach zachęcających do wstąpienia w szeregi organizacji kobiety wyglądają na niezwykle zadbane: ich mundury są czyste i dobrze dopasowane, a na twarzach widnieje niemal wyjściowy makijaż (Recruiting Women 1942; Imperial War Museum bd). Takie wzorce najwyraźniej przemawiały do kobiet. Żołnierki służące na Malcie, których wspomnienia badał Chris Bailey, wspominają, jak bardzo dbały o swój wygląd (Bailey 1993: 58). Z tych przykładów wynika, że osoby służące w WRNS

7 Tłumaczenie autora. 
były postrzegane w pierwszej kolejności jako kobiety, a dopiero później jako żołnierze. W WRNS często przekładano tradycyjne role płciowe nad względy praktyczne.

Większość kobiet wstępujących do WRNS była niezamężna. Te, które wstępowały w wieku 18 lat (minimalnym wieku mobilizacji), w warunkach pokojowych zaczynałyby zakładać rodziny. W kobiecych służbach pomocniczych kontakty z mężczyznami były jednak oficjalnie ograniczone. Muriel Bacon (2004), która służyła w WRNS na Orkadach, wspomina, że w kinie garnizonowym były wręcz oddzielne rzędy dla kobiet i dla mężczyzn. W praktyce jednak kontakty pomiędzy kobietami z WRNS a żołnierzami Royal Navy i innych formacji były dość powszechne. Niektóre wspomnienia zawierają informacje o zabawach czy rozgrywkach sportowych, w których kobiety z WRNS brały udział wspólnie z żołnierzami brytyjskimi i cudzoziemcami, w tym również z Polakami (Swift 2004; Evans 2005; Thomas 2004). Bywało, że kobiety poznawały w wojsku swoich przyszłych mężów - na przykład Olive Swift jako mechanik wWRNS współpracowała z oficerem, za którego później wyszła (Swift 2004). Doświadczenia małżonków, którzy wspólnie znosili trudy wojny, były radykalnie różne od doświadczeń małżeństw przedwojennych. Trudno ocenić wpływ tych doświadczeń na późniejsze relacje pomiędzy małżonkami: wspomnienia zgromadzone przez British Broadcasting Corporation w większości kończą się w momencie zakończenia wojny i demobilizacji. Na podstawie doświadczeń innych par, które wspólnie przeżyły wojnę (jak na przykład wspomnianej już Nelli Last), można jednak przypuszczać, że pozycja kobiet wobec mężczyzn przynajmniej w niektórych przypadkach zaczęła ewoluować z podrzędnej na partnerską.

\section{Sytuacja finansowa}

Kobiety służące w WRNS dostawały żołd, który w wypadku niższych rangą wynosił 8-10 szylingów tygodniowo (Bailey 1993: 61; Mason 2011: 39). Przeliczając to na wartość nabywczą w roku 2005, żołd ten wynosił 10,38 funta tygodniowo - czyli stosunkowo niewiele (The National Archives bd.). Warto zaznaczyć, że mężczyźni na podobnych stanowiskach zarabiali 14 szylingów (BBC News 2006). Różnica w rozumieniu użyteczności kobiet i mężczyzn dla armii znajdowała więc odzwierciedlenie w zarobkach - ci ostatni zarabiali niemal dwa razy więcej. Można zatem stwierdzić, że wojna nie wyeliminowała nierówności w płacach - poza nielicznymi wyjątkami w świecie pozamilitarnym kobiety również zarabiały około 50 procent pensji mężczyzn zatrudnionych na tych samych stanowiskach ${ }^{8}$ (Bruley 1999: 99). Warto jednak zaznaczyć, że pensje w Royal Navy były niskie w porównaniu z zarobkami w sektorze cywilnym. Choć w miare awansu i uzyskiwania nowych kwalifikacji płace kobiet wzrastały (wykwalifikowana Leading Wren zarabiała ponad 18 szylingów, a wykwalifikowana Chief Wren ponad 23 szylingi), Mason zaznacza, że dla wielu kobiet wstąpienie do WRNS było „znaczącym poświęceniem finansowym" (Mason 2011: 38-39). Można więc domyślać się,

8 Warto zaznaczyć, że podczas wojny parlamentarzystki podejmowały próby wyrównania pensji kobiet i mężczyzn. Udało się to osiągnąć na przykład w branży edukacyjnej. 
że ich główną motywacją nie był zarobek, a możliwość przyczynienia się do zwycięstwa Wielkiej Brytanii i aliantów w wojnie.

Z finansowego puktu widzenia służba w WRNS była więc istotna nie tyle ze względu na same zarobki, co na ich symboliczne znaczenie: kobiety żołnierze uzyskały niespotykaną wcześniej niezależność finansową. Już choćby fakt, że armia zapewniała im zakwaterowanie i wyżywienie, był odejściem od przedwojennej normy, kiedy zaspokojenie podstawowych potrzeb zależało w znacznej mierze od pracy męża bądź ojca. Ponadto kobiety same dysponowały pieniędzmi, które zarobiły. Chris Bailey zaznacza, że dopiero podczas służby zaczęły one „uświadamiać sobie, w jakim stopniu kontrolują własne życie" (Bailey 1993: 61). I choć w tym konkretnym przypadku na wewnętrzną przemianę kobiet z pewnością miała wpływ zmiana otoczenia z konserwatywnej Wielkiej Brytanii na bardziej w tamtym czasie liberalną Maltę, to możliwość dysponowania własnymi pieniędzmi niewątpliwie uświadomiła im, że nie muszą zależeć finansowo od mężczyzn.

\section{Podsumowanie}

Choć służba w WRNS znacząco wpłynęła na sytuację kobiet, to wpływ ten nie objął wszystkich obszarów życia. W wielu przypadkach nie okazał się też trwały. Nie ulega wątpliwości, że II wojna światowa przyniosła radykalne zmiany w życiu wielu brytyjskich kobiet, niezależnie od tego, czy służyły one w WRNS, innych siłach pomocniczych, pracowały w przemyśle, czy zajmowały się rodziną. Te, które spędziły część bądź całość wojny w formacjach pomocniczych marynarki wojennej, opuściły swoje tradycyjne środowiska i diametralnie zmieniły styl życia: zdobyły nową pracę, zaczęły inaczej się ubierać, dopasowywały się do zupełnie innych norm zachowania. Kobiety żołnierze uświadomiły sobie, że nie muszą zależeć od mężczyzn. Choć współpracowały z nimi, to przecież często przyjmowały rozkazy od swoich przełożonych - kobiet (WRNS było organizacją w całości zarządzaną i administrowaną przez kobiety; Mason 2011: 50); zarabiały także na swoje utrzymanie i przyjemności. Zarówno wśród nich samych, jak i wśród reszty społeczeństwa coraz popularniejsze stawało się przekonanie, że kobiety mogą wykonywać pracę wymagającą wysokich kwalifikacji i zajmować się tradycyjnie męskimi czynnościami, jak na przykład obroną ojczyzny. Znamienne wydaje się i to, że - w przeciwieństwie do sytuacji po I wojnie światowej - WRNS nie zostało zlikwidowane i istniało aż do lat 90 ., kiedy to zostało zintegrowane z regularną brytyjską marynarką wojenną.

Pomimo tego społeczeństwo i władze oczekiwały od kobiet typowo kobiecego zachowania i podkreślały ich podrzędność wobec mężczyzn. Po wojnie zlikwidowano wiele ułatwień dla kobiet pracujących, jak na przykład niektóre żłobki, i oczekiwano, że mężczyźni wrócą na swoje przedwojenne miejsca pracy (Gardiner 2005: 686). Sytuacja panująca w trakcie wojny określana była jako tymczasowa (Gardiner 2005: 532-533) i tak też podchodziły do niej same kobiety. Nie należy zapominać, że pomimo

9 Tłumaczenie autora. 
wszystkich pozytywnych przemian społecznych, jakie zaszły w latach 1939-1945, był to przede wszystkim czas konfliktu zbrojnego. Wiele osób, zarówno mężczyzn, jak i kobiet, żyło w strachu przed śmiercią. Podstawowe dobra były racjonowane, rodziny rozbite, a część domów zniszczona. Nie inaczej niż mężczyźni, znaczna część kobiet z WRNS i innych formacji pomocniczych uważała za swój ostateczny cel powrót do sytuacji przedwojennej. I rzeczywiście, po zakończeniu działań wojennych większość kobiet powróciła do swoich tradycyjnych ról płciowych.

\section{Literatura}

Bacon M., 2004, The Orkney Isles - Late WW2, http://www.bbc.co.uk/history/ww2peopleswar/stories/11/a2692811.shtml [dostęp: 18.10.2017].

Bailey C., 1993, "Ambassadors of England": Work and Leisure for the Wrens in Malta, 1944-1950, "Oral History", t. 21, nr 2.

BBC News, 2006, Were soldiers ever well paid? http://news.bbc.co.uk/1/hi/magazine/6040406.stm [dostęp: 11.09.2015].

Boothroyd M., 2004, In the WRNS with Laura Ashley, http://www.bbc.co.uk/history/ww2peopleswar/ stories/46/a2939646.shtml [dostęp: 18.10.2017].

British Broadcasting Corporation, 2014, WWII: People's War (archiwum internetowe projektu), http:// www.bbc.co.uk/history/ww2peopleswar/categories/c1186/index.shtml [dostęp: 11.09.2015].

Bruley S., 1999, Women in Britain since 1900, Basingstoke: Macmillan.

Calder A., 1969, The People's War: Britain 1939-45, London: Jonathan Cape.

Domenico D., Jones K., 2006, Career Aspirations of Women in the 20th Century, "Journal of Career and Technical Education", t. 22, $\mathrm{nr} 2$.

Evans J., 2005, A Bird's Eye View of the Yalta Conference by A Wren, http://www.bbc.co.uk/history/ ww2peopleswar/stories/12/a4336012.shtml [dostęp: 18.10.2017].

Fletcher M. H., 1989, The WRNS: A History of the Women's Royal Naval Service, Annapolis: Naval Institute Press.

Gardiner J., 2005, Wartime: Britain 1939-1945, London: Headline Book Publishing.

Hallowell, H., 2003, Life as a Wren, http://www.bbc.co.uk/history/ww2peopleswar/stories/02/ a1902502.shtml [dostęp: 18.10.2017].

Hellbeck J., 2015, Battles for morale: An entangled history of total war in Europe, 1939-1945, (w:) The Cambridge History of the Second World War, red. M. Geyer, A. Tooze, Cambridge: Cambridge University Press.

Higham A., 1942, Women in Defense of Britain: An Informal Report, „Journal of Educational Sociology", t. 15, nr 5 .

Horton E., 2004, D-Day Experience: A Wren at Portsmouth, http://www.bbc.co.uk/history/ww2peopleswar/stories/38/a2366138.shtml [dostęp: 18.10.2017].

House of Commons Information Office, 2010, Women in the House of Commons. http://www.parliament.uk/documents/commons-information-office/m04.pdf [dostęp: 11.09.2015].

Imperial War Museum, [brak daty wydania], Join the Wrens - and Free a Man for the Fleethttp://www. iwm.org.uk/collections/item/object/29092 [dostęp: 15.09.2015]. 
Last N., 2006, Nella Last's War. The Second World War Diaries of 'Housewife, 49', red. R. Broad, S. Fleming, wyd. 2, Londyn: Profile Books.

Malone M., 2003, Overlord, http://www.bbc.co.uk/history/ww2peopleswar/stories/03/a2047303. shtml [dostęp: 18.10.2017].

Marion (nazwisko nieznane), 2003, The Listeners: WRNS Listening Posts, http://www.bbc.co.uk/history/ww2peopleswar/stories/03/a2059003.shtml [dostęp: 18.10.2017].

Marwick A., 1988, Britain in the Century of Total War, London: Bodley Head.

Mason U. S., 2011, Britannia's Daughters: The Story of the WRNS, Barnsley: Pen and Sword Military.

Morgan G., 2005, Teenage Years in the Wrens, http://www.bbc.co.uk/history/ww2peopleswar/stories/10/a4109410.shtml [dostęp: 18.10.2017].

Olive (nazwisko nieznane), 2005, Olive Joins the WRENs, http://www.bbc.co.uk/history/ww2peopleswar/stories/24/a4124224.shtml [dostęp: 18.10.2017].

Recruiting Women - Trailer, 1942, Government Official, 16.11.1942, https://www.britishpathe.com/ video/recruiting-women-trailer/query/wrns [dostęp: 9.12.2017].

Rice P., 2005, Pauline Rice - evacuee to W.R.N.S., http://www.bbc.co.uk/history/ww2peopleswar/stories/97/a5248497.shtml [dostęp: 18.10.2017].

Rowbotham S., 1999, A Century of Women: The History of Women in Britain and the United States, London: Penguin.

Smith H. L., 1986, The effect of the war on the status of women, (w:) War and social change: British society in the Second World War, red. H.L. Smith, Manchester: Manchester University Press.

Summerfield P., 1998a, Reconstructing women's wartime lives: Discourse and subjectivity in oral histories of the Second World War, Manchester: Manchester University Press.

Summerfield P., 1988b, Women, War and Social Change: Women in Britain in World War Il, (w:) Total War and Social Change, red. A. Marwick, Basingstoke: Macmillan.

Swift O., 2004, One Wren's War, http://www.bbc.co.uk/history/ww2peopleswar/stories/09/a3429209. shtml [dostęp: 18.10.2017].

The National Archives, [1919], Sex Disqualification (Removal) Act 1919, http://www.legislation.gov. uk/ukpga/Geo5/9-10/71/contents/enacted [dostęp: 22.06.2016].

The National Archives, [brak daty wydania], Currency Converter (kalkulator walut historycznych), http://www.nationalarchives.gov.uk/currency/ [dostęp: 14.09.2015].

The Open University, [brak daty wydania], The Wrens - Women's Royal Naval Service, http://caber. open.ac.uk/schools/stanway/Wrens_poster.html [dostęp: 15.09.2015].

Thomas G., 2004, Ginger Thomas's D-Day: Working for Cossac, http://www.bbc.co.uk/history/ww2peopleswar/stories/02/a2524402.shtml [dostęp: 18.10.2017].

W.R.N.S. At The Helm, 1944, Pathe Gazette, 25.12.1944, https://www.britishpathe.com/video/w-r-n-s-at-the-helm/query/wrns [dostęp: 10.12.2017].

Wallace E. M., 2003, The Admiral's Safe: The Responsibility of Issuing D-Day Orders, http://www.bbc. co.uk/history/ww2peopleswar/stories/76/a2047376.shtml [dostęp: 18.10.2017].

Weigall D., 2002, International Relations: A Concise Companion, London-New York: Arnold.

Women of the Navy, 1943, Pathe Gazette, 15.04.1943, https://www.britishpathe.com/video/women-of-the-navy/query/wrns [dostęp: 10.12.2017].

Wrens in the Middle East, 1942, Pathe Gazette, 29.10.1942, https://www.britishpathe.com/video/ wrens-in-the-middle-east/query/wrns [dostęp: 10. 12.2017]. 